\title{
ANALYSIS OF FACTORS AFFECTING PRODUCTION AND REVENUE OF TUBEROSE (Polianthes tuberosa L.) FARMERS IN PRODUCTION CENTER OF CENTRAL JAWA
}

\author{
Ani Mulynani ${ }^{1}$, Titik Ekowati ${ }^{2}$, and Endang Dwi Purbajanti ${ }^{2}$ \\ ${ }^{1}$ Department of Agriculture and Plantation of Central Java Province, \\ Semarang, Central Java, Indonesia \\ ${ }^{2}$ Faculty of Animal and Agricultural Sciences, Universitas Diponegoro, \\ Semarang, Central Java, Indonesia \\ Correspondence Email : mulyani.ani@,outlook.com
}

Submitted 9 June 2020; Accepted 28 November 2020

\begin{abstract}
ABSTRAK
Bunga Sedap Malam (Polianthes tuberosa L.) merupakan salah satu jenis bunga potong yang banyak diminati oleh florist karena keharumannya dan tidak mudah layu. Sentra produksi di Jawa Tengah terdapat di Kabupaten Magelang dan Kabupaten Semarang. Penelitian ini bertujuan untuk mengetahui faktor-faktor yang mempengaruhi produksi, pendapatan petani dan kelayakan usahatani bunga Sedap Malam. Metode penelitian adalah metode sensus, jumlah sampel 30 responden, lokasi kabupaten Semarang dan Magelang. Analisis data menggunakan fungsi produksi model Cobb Douglas, fungsi linier regresi dan one sample $t$ test. Hasil analisis fungsi produksi bahwa jumlah benih, jumlah pupuk organik, jumlah pupuk NPK, jumlah tenaga kerja, dan jumlah air berpengaruh nyata. Hasil analisis fungsi pendapatan yang berpengaruh nyata adalah harga bunga dan jumlah produksi, artinya jika terjadi kenaikan harga bunga atau kenaikan jumlah produksi maka pendapatan petani akan meningkat. Hasil one sample $t$ test bahwa usaha tani Bunga Sedap Malam menguntungkan dan layak untuk dikembangkan.
\end{abstract}

Kata kunci: pendapatan, produksi, sedap malam

\section{ABSTRACT}

The purpose of this research is to analysis the effect of using production factors, farmer income and feasibility on Tuberoses flower (Polianthes tuberosa L.) crops. Research used census method and the number of sampel are 30 respondents, in Semarang and Magelang regency. Analysis of research used Cobb-douglas model of production function, linier regression function and one sample t test. The results of the analysis of production function showed the amount of seeds, organic fertilizer, NPK fertilizer, labor and the water have significant effect. The results of the analysis of the income function that have significant effect were the price and the amount of production, this means, if increase in prices or increase in production, the farmer's income will increase. One samplet $t$ - test results showed tuberose flowers farming was profitable and feasible to be developed.

Key words: income, production, tuberoses flower

\section{INTRODUCTION}

Tuberose flowers or Sedap Malam (Polianthes tuberosa L.) from the Amaryllis family (Amaryllidaceae) is a commodity of beautiful cut-flower plants with single and double flowers that are popular among the florists to complement a flower arrangement because of their distinct fragrance compared to other ornamental plants (Department of Agriculture and Food Security, Bandung City, 2008). Production centers in Central Java are 
located in Magelang Regency and Semarang Regency. The development of ornamental plant agribusiness, production problems, productivity, continuity, and quality are the factors causing the weak bargaining position of farmers.

The factors that influence the success of ornamental plant farming are the use of improved seeds, fertilization, prevent the attacks of plant pests, and irrigation according to the needs of plants which must be considered (Wasito and Tedjasarwana, 2003). Some of these things are in accordance with Chang's (1998) viewpoint that the productivity of the Tuberose plant is influenced by several factors including water, nutrients, temperature, humidity, and sunlight intensity. According to Baruah and Talukdar (1998), it is necessary to know the plant responses to the application of fertilizers/nutrients to increase flower productivity and quality. From the results of previous tests, it has been found that Tuberose plants need $\mathrm{N}, \mathrm{P}$, and $\mathrm{K}$ nutrients to support growth and production. However, in these tests, the dose that gives the best production value has not been obtained.

The results of the Tuberose research which can be used as a reference for the cultivation of Tuberose flowers are a spacing of $20 \times 20 \mathrm{~cm}$, the provision of a growth regulator substance paclobutrazol $300 \mathrm{ppm}$ (Komariah, 1990; Santi et al., 1996). The use of medium sized seeds $(2,5-3 \mathrm{~cm}$ in diameter) and the application of fertilizer at a dose of $1 \mathrm{~kg} / \mathrm{m}^{2} /$ year, especially on latosol soil, are the main packages to support the growth and high production of Tuberose Flowers (Sharga, 1989; Ram et al.,1999; Singh, 2000). Manure can be used as a growing medium because it can affect soil fertility both physically, chemically, and biologically. It can improve soil structure in the root area, increase soil aeration, and withstand the loss of major nutrients such as nitrogen and phosphorus from the soil (Williams et al., 1993).

Tuberose flower farming requires a long time of farming, which is two years from planting to replanting with a multiple harvest system, and begins to harvest at the age of 7 months after planting. Thus, Tuberose farmers require large farming costs. The research results by Ardiansyah et al. (2013) showed that the production cost of Tuberose flowers in Rembang village, Rembang sub-district, Pasuruan Regency was IDR 69,379,200/planting season/ha. Every farmer in carrying out their farming takes into account the costs and yields to be obtained so that they do not experience losses, taking into account the various risks of crop failure, the possibility of falling market prices at harvest time, and uncertainty of the season.

Tuberose cultivation business in Magelang and Semarang regencies has been developed since 1970 and has become an additional income besides rice farming. Farmers generally run farming without recording and calculating the costs because they only focusing on production. Previous studies only examined factors affecting production or factors affecting farmers' income separately. Meanwhile, the objective of this study was to analyze the effect of using seeds, fertilizers, substances, labor, and water availability on production and costs on farmers' income so that Tuberose farming is profitable or not to be developed.

\section{RESEARCH METHOD}

This study used the census method with a sample size of 30 respondents. This study was conducted in Semarang and Magelang Regencies, which are the centers for the production of Tuberose flowers in Central Java in 2017. Production analysis used the Cobb Douglas model production function. Farmer revenue analysis used a linear regression function, one-sample t-test, and Profitability Index (PI)

The analysis of the production function of the Cobb Douglas model to determine the effect of the number of seeds, the amount of organic fertilizer, the amount of NPK fertilizer, the number of pesticides, the amount of labor, and the amount of water on 
the production of flowers produced is formulated as follows:

$$
\begin{gathered}
\operatorname{Ln} Y=\ln a+b_{1} \ln X_{1}+b_{2} \ln X_{2}+b_{3} \ln X_{3} \\
+b_{4} \ln X_{4}+b_{5} \ln X_{5}+b_{6} \ln X_{6}+\ln \mathrm{e}
\end{gathered}
$$

Information:

$$
\begin{array}{ll}
\mathrm{Y} & =\text { Production (stalk) } \\
\mathrm{a} & =\text { Constant } \\
\mathrm{b}_{1}, \ldots \mathrm{b}_{6} & =\text { Coefficient } \\
\mathrm{X}_{1} & =\text { Seed }(\mathrm{kg}) \\
\mathrm{X}_{2} & =\text { Organic fertilizer }(\mathrm{kg}) \\
\mathrm{X}_{3} & =\text { NPK }(\mathrm{kg}) \\
\mathrm{X}_{4} & =\text { Pesticide (liter) } \\
\mathrm{X}_{5} & =\text { Labor (HOK) } \\
\mathrm{X}_{6} & =\text { Water (liter) } \\
\mathrm{e} & =\text { Error }
\end{array}
$$

Analysis of the effect of factor costs of production on income uses the following formula:

$$
\begin{gathered}
Y=a+b_{1} X_{1}+b_{2} X_{2}+b_{3} X_{3}+b_{4} X_{4}+b_{5} X_{5}+ \\
b_{6} X_{6}+b_{7} X_{7}+b_{8} X_{8}+e
\end{gathered}
$$

Information:

$\mathrm{Y} \quad=$ Income $(\mathrm{Rp} /$ growing season $)$

a $\quad=$ Constant

$\mathrm{b}_{1}, \ldots \mathrm{b}_{8}=$ Coefficient

$\mathrm{X}_{1} \quad=$ Flower price $(\mathrm{Rp})$

$\mathrm{X}_{2} \quad=$ Flower production (stalk)

$\mathrm{X}_{3} \quad=$ Land rent cost $(\mathrm{Rp})$

$\mathrm{X}_{4} \quad=$ Seed cost $(\mathrm{Rp})$

$\mathrm{X}_{5} \quad=$ Organic fertilizer cost $(\mathrm{Rp})$

$\mathrm{X}_{6} \quad=$ NPK fertilizer cost (Rp)

$\mathrm{X}_{7} \quad=$ Pesticide cost $(\mathrm{Rp})$

$\mathrm{X}_{8} \quad=$ Labor cost $(\mathrm{Rp})$

$\mathrm{e} \quad=$ Error
The test to determine that the Tuberose Flower farming is profitable and feasible to develop was conducted by using a one-sample t-test comparison test between the profitability of the Tuberose Flower farm and commercial bank loan interest $(17,5 \%)$ as well as bank deposit interest (4,5\%).

\section{RESULT AND DISCUSSION}

Inputs of production facilities which usually used by farmers in the cultivation of Tuberose Flowers are seeds, organic fertilizers, inorganic fertilizers, pesticides, water, labor, newspapers, rope, and transportation as shown in Table 1. The seeds used by farmers come from the Bulbs of the Tuberose plant which is two years old and has been dried and the dormancy is broken which is indicated by the release of buds. The average use of Tuberose seeds is $1.063 \mathrm{~kg} / \mathrm{ha}$. Farmers usually buy seeds due to time efficiency. Tuberose plants are propagated by bulbs and the separation of tillers. Bulbs are taken from production plants that are more than 2,5 years old. Harvested bulbs will enter a period of dormancy (rest period) and therefore it is necessary to store for 1-2 months so that the concentration of growth inhibitors in the bulbs decreases and when the bulbs are planted, shoots will grow faster (Indonesian Ornamental Crops Research Institute, 2015).

Fixed costs are costs incurred in farming which the size does not depend on the size of the output obtained (Soekartawi, 2016).

Table 1. Average Input of Tuberose Flower Farming in 2017 (ha/growing season)

\begin{tabular}{cccc}
\hline No & Input & Unit & Total \\
\hline 1 & Seed & $\mathrm{kg}$ & 1.063 \\
2 & Organic fertilizer & $\mathrm{kg}$ & 7.323 \\
3 & NPK fertilizer & $\mathrm{kg}$ & 1.113 \\
4 & Pesticide & liter & 26 \\
5 & Water & liter & 1.356 \\
6 & Labor & hok & 1.310 \\
7 & Newspaper & $\mathrm{kg}$ & 62 \\
8 & Rope & $\mathrm{kg}$ & 24 \\
9 & Transportation & $\mathrm{rp}$ & 10.410 .464 \\
\hline
\end{tabular}

Source: Primary Data 
Table 2. Average Fixed Costs of Tuberose Flower Farming in 2017 (ha/growing season)

\begin{tabular}{cccc}
\hline No & Fixed Cost & Total (Rp/growing season) & Percentage (\%) \\
\hline 1 & Land rent & 11.872 .167 & 92,79 \\
2 & Land tax & 126.667 & 0,99 \\
3 & Depretiation & 795.613 & 6,22 \\
\hline & Total & 12.794 .447 & 100,00 \\
\hline
\end{tabular}

Source: Primary Data

Table 3. Average Variable Costs of Tuberose Flower Farming in 2017 (ha/growing season)

\begin{tabular}{|c|c|c|c|c|c|c|}
\hline No & Input & Unit & Total & $\begin{array}{l}\text { Price per Unit } \\
\text { (Rp) }\end{array}$ & $\begin{array}{c}\text { Cost } \\
\text { (Rp/growing } \\
\text { season) }\end{array}$ & $\begin{array}{c}\text { Percentage } \\
(\%)\end{array}$ \\
\hline 1 & Seed & $\mathrm{kg}$ & 1.063 & 3.292 & 3.500 .063 & 4,68 \\
\hline 2 & $\begin{array}{l}\text { Organic } \\
\text { fertilizer }\end{array}$ & $\mathrm{kg}$ & 7.323 & 411 & 3.009 .890 & 4,03 \\
\hline 3 & NPK fertilizer & $\mathrm{kg}$ & 1.113 & 2.487 & 2.767 .730 & 3,70 \\
\hline 4 & Pesticide & liter & 26 & 110.868 & 2.882 .575 & 3,86 \\
\hline 5 & Water & liter & 1.356 & 450 & 610.368 & 0,82 \\
\hline 6 & Labor & hok & 1.310 & 38.565 & 50.520 .403 & 67,60 \\
\hline 7 & Newspaper & $\mathrm{kg}$ & 62 & 4.580 & 284.008 & 0,38 \\
\hline 8 & Rope & $\mathrm{kg}$ & 24 & 31.127 & 747.060 & 1,00 \\
\hline \multirow[t]{2}{*}{9} & Transportation & $\mathrm{rp}$ & - & & 10.410 .464 & 13,93 \\
\hline & Total & & & & 74.732 .561 & 100,00 \\
\hline
\end{tabular}

Source: Primary Data

The average fixed cost in this study is IDR 12.794.447,- which is used for land leases, land taxes, and depreciation costs for agricultural equipment, namely hoes, sickles/machetes, and hand sprayers.

Variable costs are costs incurred for farming which the size is influenced by the output obtained (Soekartawi, 2016). In this study in the form of labor and agricultural production facilities (Saprotan) includes seeds, organic fertilizers, NPK fertilizers, pesticides, labor wages, newspapers, rope, and transportation costs. The average variable cost incurred by farmers is IDR 74.732.561,-

Simultaneous hypothesis testing (F Test) is used to test the significance of the effect of the independent variables together on the dependent variable. The results of the $\mathrm{F}$ test are in accordance with Table 4 . It is obtained a significance value of 0,001 , so $\mathrm{H} 0$ is rejected.

Table 4. Simultaneous Hypothesis Testing (Test F) Effect of Production Factors on Tuberose Flower Production.

\begin{tabular}{lrrrrr}
\hline \multicolumn{1}{c}{ Model } & Sum of Square & \multicolumn{1}{c}{ Df } & Mean Square & F & \multicolumn{1}{c}{ Sig } \\
\hline Regression & 0,954 & 6 & 0,159 & 6,192 &, $001^{\mathrm{b}}$ \\
Residual & 0,646 & 23 & 0,028 & & \\
Total & 1,600 & 29 & & & \\
\hline
\end{tabular}

Predictors: (Constant), Pesticide, Organic fertilizer, Seed, NPK fertilizer, Labor, Water Dependent Variable: Production 
This means that all variables of the number of seeds, organic fertilizers, NPK fertilizers, pesticides, and labor have a highly significant effect on the production of Tuberose flowers.

The results of the analysis of the effect of production factors on the production of Tuberose flowers (t-test) obtained the equation as follows:

$$
\begin{gathered}
\operatorname{LnY}=9,697+0,158 \operatorname{Ln} X_{1}-0,170 \operatorname{LnX}_{2}+ \\
0,120 \operatorname{Ln} X_{3}-0,085 \operatorname{Ln} X_{4}+0,214 \operatorname{Ln} X_{5}+ \\
0,102 \operatorname{Ln} X_{6}
\end{gathered}
$$

The solution of the Cobb Douglas model function must be transformed into a linear function, the requirements that must be met are:

1. No observation value is zero because the logarithm of zero is a number whose magnitude is unknown

2. In the production function, it is necessary to assume that there is no difference in technology in each observation. This means that if the production function used in the observation requires more than one model, then the difference lies in the intercept and not in the slope of the model.

3. Each variable $\mathrm{x}$ is perfect competition

4. Differences in a location such as a climate are included in the disturbance term

The regression equation is subjected to a natural anti-logarithmic transformation so that the Cobb Douglas production function is obtained as follows:

$\mathrm{Y}=16.269 \mathrm{X}_{1}^{0,158} \mathrm{X}_{2}^{-0,170} \mathrm{X}_{3}^{0,120} \mathrm{X}_{4}^{-0,085} \mathrm{X}_{5}^{0,214}$
$\mathrm{X}_{6}^{0,102}$
The regression equation can be explained as follows:

1. The number of seeds produces a coefficient of 0,158 with a significant value of 0,013 , which is positive and has a significant effect on the production of Tuberose flowers. The coefficient value of 0,158 means that every 1 percent increase in seeds can increase the production of Tuberose flowers by 0,158 percent.

The results of respondent data show different plant spacing, namely $30 \times 30$; $40 \times 30 ; 40 \times 40$. The spacing of farmers in the Magelang Regency is closer than the farmers of the Semarang Regency. For a denser spacing, it requires the use of more seeds, and the number of plants in one hectare reaches 120.000 plants, the number of flowers in one clump can reach 25 stalks, the use of sufficient fertilizer and intensive maintenance will produce a large number of Tuberose flowers and good plant vigor. According to Rukmana (1995), the method of multiplication of tuberose is through propagation by bulbs which are pseudostems that change shape and function as food reserves. Each plant consists of one or more parent bulbs and also a group of child bulbs. Large bulbs produce flowers faster than medium bulbs and small-size bulbs (Tejasarwana et al., 2004). According to Sihombing, et al. (2012), this is related to the availability of sufficient nutrients in medium $(1,5-2,5$ $\mathrm{cm})$ and large $(>2,5 \mathrm{~cm})$ bulbs.

Table 5. Results of Analysis of the Influence of Production Factors on Tuberose Flower Production

\begin{tabular}{cccccc}
\hline Model & $\begin{array}{c}\mathrm{B} \\
\text { Coefficient }\end{array}$ & $\mathrm{t}$ & Sig. & $\begin{array}{c}\text { Partial } \\
\text { Correlation }\end{array}$ & VIF \\
\hline Constant & 9,697 & 9,989 &, 005 & & \\
Ln Seed & 0,158 & 2,041 &, 013 & 0,392 & 1,053 \\
Ln Organic fertilizer & $-0,170$ & $-4,168$ &, 001 & $-0,656$ & 1,344 \\
Ln NPK fertilizer & 0,120 & 1,608 &, 034 & 0,318 & 1,256 \\
Ln Pesticide & $-0,085$ & $-1,549$ &, 106 & $-0,307$ & 1,235 \\
Ln Labor & 0,214 & 3,106 &, 014 & 0,544 & 1,179 \\
Ln Water & 0,102 & 1,888 &, 047 & 0,366 & 1,323 \\
\hline
\end{tabular}

Source: Primary Data 
Therefore, they can produce plants that are more fertile and grow faster. The number of seeds used by the farmers of the Semarang Regency per $1,000 \mathrm{~m}^{2}$ is 2 sacks $(80 \mathrm{~kg})$. While in Magelang Regency the use of seeds per $1,000 \mathrm{~m}^{2}$ is an average of 3 sacks $(120 \mathrm{~kg})$. Meanwhile, each planting hole uses 1 rhizome. The flower production from Semarang Regency is bigger and stronger from the appearance/vigor. The quality of A-class flowers is more than the flowers from the Magelang Regency which has a higher number of harvests. The use of seeds is still local. There are no seed breeders available so that there are no seed providers who select quality and similar seeds. The use of improved seeds can increase flower production because one good and quality bulb can produce a higher number of flowers.

2. The application of organic fertilizer produces a coefficient of $-0,170$ with a significant value of 0,001 , which is negative and has a significant effect on the production of Tuberose flowers. The coefficient value is $-0,170$ means that every 1 percent increase in organic fertilizer can reduce the tuberose flower production by 0,170 percent. Organic fertilizers commonly used by farmers are in the form of manure from cow or chicken manure. According to Hartatik and Widowati (2006), that manure is bulky with low macro and micronutrient content so that it needs large amounts of fertilizer. In addition to containing beneficial nutrients, manure also contains saprolytic bacteria, disease carriers, and parasites of microorganisms, and carriers of weed seed. The use of immature manure and improper dosage to the needs of the plants can have a negative effect on plants because it increases soil acidity and becomes a source of soil-borne diseases.

3. Application of NPK fertilizer produces a coefficient of 0,120 with a significant value of 0,034 , which is positive and has a significant effect on the production of
Tuberose flowers. The coefficient value of 0,120 means that every 1 percent increase in NPK fertilizer can increase the production of Tuberose flowers by 0,120 percent. This is in accordance with the opinion of Wasito and Tedjasarwana (2003), that the Tuberose plant with good growth in a place is not much determined by the cultivar but is more determined by the number of nutrients given. The greater the number of elements as long the composition between $\mathrm{N}, \mathrm{P}$, and $\mathrm{K}$ is balanced, then the better plants will grow and give good flower yields.

4. The use of pesticides produces a coefficient of $-0,085$ with a significant value of 0,106 , which is negative and does not affect the production of Tuberose flowers $(0,106>0,05)$. This is because the provision of pesticide substance is not according to the dosage $(0,5-1 \mathrm{ml} /$ liter $)$. Farmers usually use a dose of $10 \mathrm{ml} / 16$ liters of water according to the capacity of the hand sprayer tank. Due to the high prices of substances, the type of pesticide used in the field is not just one type of pesticide but adjusted to the needs and conditions in the field.

5. The number of labor produces a coefficient of 0,214 with a significant value of 0,014 which is positive and has a significant effect on the production of Tuberose flowers. The coefficient value of 0,214 means that every 1 percent increase in labor can increase the production of Tuberose flowers by 0,214 percent. The cultivation of Tuberose flowers based on respondent data involves male and female farmers. The male farmers play an extremely important role when cultivating the land from digging to making beds. While female farmers are involved in planting, maintaining, and post-harvesting.

6. The use of the amount of water produces a coefficient of 0,102 with a significant value of 0.047 , which is positive and has a significant effect on the production of Tuberose flowers. 
Table 6. Tuberose Farmers' Income (ha/growing season)

\begin{tabular}{cc}
\hline Description & Total (Rp/growing season) \\
\hline Revenue & 244.491 .833 \\
Cost & 87.527 .008 \\
Income & 156.964 .825 \\
\hline
\end{tabular}

Source: Primary Data

The coefficient value of 0,102 means that every 1 percent increase in water can increase the production of Tuberose flowers by 0,102 percent.

This is according to Chang's (1998) opinion that the productivity of the Tuberose plant is influenced by several factors including water, nutrients, temperature, humidity, and sunlight intensity. To meet the water needs in the dry season, farmers are willing to pay to take the water from the river using a pump. According to Shinta (2011), Agricultural income is the difference between income earned or revenue generated and all costs. Based on the data in Table 13, the income of the farmers of Tuberose flowers per hectare per season is IDR 156.964.825,-

The result of the adjusted $\mathrm{R}^{2}$ is 0,795 which means that $79,5 \%$ of the income of the farmers of Tuberose flowers in Semarang and Magelang regencies are influenced by the price of flower, total production, land lease costs, seed costs, organic fertilizer costs, NPK fertilizer costs, pesticide costs, and labor costs.

The results of the $\mathrm{F}$ test obtained a significance value of 0,000 , so Ho is rejected, meaning that all variables jointly have a very significant effect on the income of the farmers of Tuberose flowers.

Table 7. Simultaneous Hypothesis Testing Results (Test F) The Effect of Production Factor Prices on the Income of the Tuberose Flower Farmers.

\begin{tabular}{ccccccc}
\hline Model & Sum of Square & Df & Mean Square & F & Sig & Adjusted \\
\hline Regression & $3,332 \mathrm{E}+17$ & 6 & $4,165 \mathrm{E}+16$ & 15,046 &, $000^{\mathrm{b}}$ &, 795 \\
Residual & $5,814 \mathrm{E}+16$ & 21 & $2,768 \mathrm{E}+15$ & & & \\
Total & $3,914 \mathrm{E}+17$ & 29 & & & & \\
\hline
\end{tabular}

Source: Primary Data

Table 8. Results of the Analysis of the Effect of Production Factor Costs on Farmers' Income

\begin{tabular}{cccccc}
\hline Model & B Coefficient & $\mathrm{t}$ & Sig. & $\begin{array}{c}\text { Partial } \\
\text { Correlation }\end{array}$ & $\mathrm{VIF}$ \\
\hline Constant & 123.981 .102 & $-1,434$ &, 166 & & \\
Flower price & $169.543,663$ & 6,391 &, 000 &, 813 & 1,645 \\
Production & $1.375,622$ & 4,557 &, 000 &, 705 & 2,012 \\
Land cost & $-8,581$ & $-1,243$ &, 227 &,- 262 & 1,076 \\
Seed cost & $-13,297$ & $-1,051$ &, 305 &,- 223 & 1,828 \\
Organic fertilizer & 3,959 &, 784 &, 442 &, 169 & 1,339 \\
$\quad$ cost & $-11,300$ & $-1,100$ &, 284 &,- 233 & 1,531 \\
NPK fertilizer cost &, 875 &, 123 &, 904 &, 027 & 1,933 \\
Pesticide cost &,- 956 & $-2,085$ &, 050 &,- 414 & 1,658 \\
Labor cost & & & & &
\end{tabular}

Source: Primary Data 
Based on Table 8, the multiple linear regression equation is obtained as follows: $\mathrm{Y}=-123.981 .102+169.543,663 \mathrm{X}_{1}+$ $1.375,622 \mathrm{X}_{2}-8,581 \mathrm{X}_{3}-13,297 \mathrm{X}_{4}+3,959$ $\mathrm{X}_{5}-11,300 \mathrm{X}_{6}+0,875 \mathrm{X}_{7}-0,956 \mathrm{X}_{8}$

The results of the t-test are used to determine the effect of each independent variable on the dependent variable. The regression equation can be explained as follows:

1. The flower price produces a coefficient of $169.543,663$ with a significant value of 0,000 , which is positive, meaning that every increase in the price of flowers of 1 rupiah/stalk will increase the farmers' income by IDR 169.543/hectare/season. The flower price per stalk is at least IDR $500-6,000$ in large quantities. However, at the retail level, the flower price is higher with an average of IDR 2,500 $10,000 /$ stalk. The increase in the flower price usually occurs during religious holidays such as Christmas, New Year, Chinese New Year, Eid Al-Fitr, and Eid Al-Adha, also during the months when weddings are held. The flower price increases due to market/consumer demand.

2. Flower Production produces a coefficient of $1.375,622$ with a significant value of 0,000 , which is positive, meaning that every increase in the amount of flower production by 1 unit will increase the farmers' income by IDR 1.375. Tuberose flower planting begins to produce at 6-7 months in small quantities, and after the 8 months the harvest of flowers is carried out 2 times a week or looking at the condition of the flowers in the land, in an area of $1,000 \mathrm{~m}^{2}$ then for 10 months it will produce 400 stalks per week, with good maintenance then flower production will be stable. The important thing is to do fertilization and maintenance after each harvest so that the plants have adequate food sources.

3. The cost of renting land produces a coefficient of $-8,851$ with a significant value of 0.227 which is negative and has no effect on farmers' income. The average land rental cost is IDR $11.872,167 /$ hectare, with an area cultivated between $1.000-$ $4.000 \mathrm{~m}^{2}$. Similar land rental costs do not have a significant effect on farmers' income.

4. The cost of seeds produces a coefficient of $-13,297$ with a significant value of 0,305 , which is negative and has no effect on farmers' income. The price of Tuberose seeds is stable and the same with a price range of IDR $3.292 / \mathrm{kg}$. The same cost of seeds has no significant effect. Most of the seeds are purchased from farmers in Magelang Regency and there have been seed and production partnerships between farmers in Magelang Regency and Semarang Regency.

5. The cost of organic fertilizer produces a coefficient of 3,959 with a significant value of 0,442 , which is positive and has no effect on farmers' income. Farmers usually buy raw and self-sufficient or selfprocessed manure. The need for organic fertilizer is 50 sacks every $1,000 \mathrm{~m}^{2}$ at a price of IDR 15.000-20.000/sack. A similar cost of fertilizer even from the same supplier has an insignificant effect of fertilizer costs on farmers' income.

6. The cost of NPK fertilizer produces a coefficient of $-11,300$ with a significant value of 0,284 , which is negative and has no effect on farmers' income. The NPK fertilizer that is commonly used by farmers of Tuberose flower is Phonska 15:15:15 which is a subsidized fertilizer with a ransom price of IDR 120.000-125.000/50 $\mathrm{kg}$. The use of similar NPK fertilizer results in the cost of NPK fertilizer having no effect on farmers' income.

7. The cost of pesticides produces a coefficient of 0,875 with a significant value of 0.904 , which means that it has no effect on farmers' income. Farmers usually use minimal amounts of pesticides because they are expensive. Farmers usually use liquid pesticides from the Trigon, Matarin, and Dursban brands at a price of IDR $110.000-120.000 /$ liter, and when the price of pesticides increases they use fewer 
pesticides and even switch to using biological pesticides, resulting in no effect of pesticide costs on farmers' income.

8. Labor costs produce a coefficient of $-0,956$ with a significant value of 0,050 , which is negative and affects farmers' income. The coefficient value is -0.956 , which means that each increase in labor costs is IDR $1 / \mathrm{HOK}$ will reduce the farmers' income by IDR 1 . This is because the use of labor during maintenance is a joint work, for example in the advanced fertilization activities along with tilling the soil, weeding, and eradicating pests, there is no job specification at work.

Analysis to determine that Tuberose flower farming is profitable and feasible to develop was conducted by using a onesample t-test on the profitability of Tuberose flower farming, in this study according to Table 9 the profitability value was $121,35 \%$.

Table 9. Profitability Analysis of Tuberose Flower Farming per year / ha

\begin{tabular}{cc}
\hline Description & Total \\
\hline Fixed cost $(\mathrm{Rp})$ & 6.397 .223 \\
Variable cost $(\mathrm{Rp})$ & 45.673 .179 \\
Total cost $(\mathrm{Rp})$ & 52.070 .402 \\
Revenue $(\mathrm{Rp})$ & 122.277 .464 \\
Revenue - Total cost $(\mathrm{Rp})$ & 70.207 .062 \\
$10 \%$ Tax $(\mathrm{Rp})$ & 7.020 .706 \\
Income $(\mathrm{Rp})$ & 63.186 .356 \\
Profitability $(\%)$ & 121,35 \\
\hline
\end{tabular}

Source: Primary Data

Table 10. Results of the Analysis of the Value of Profitability with Bank Loan Interest (One Sample t test)

\begin{tabular}{cc}
\hline & Profitability \\
\hline T & 7,645 \\
Sig (2-tailed) & 29 \\
Mean Difference & 0,000 \\
$95 \%$ Confidence Interval of Difference & 108,11000 \\
- Lower & \\
- Upper & 79,1865 \\
\hline
\end{tabular}

Source: Primary Data

Table 11. Results of the Analysis of the Value of Profitability with Bank Deposit Interest (One Sample $\mathrm{t}$ test)

\begin{tabular}{cc}
\hline & Profitability \\
\hline T & 8,564 \\
Df & 29 \\
Sig (2-tailed) & 0,000 \\
Mean Difference & 121,11000 \\
$95 \%$ Confidence Interval of Difference & \\
- Lower & 92,1865 \\
- Upper & 150,0335 \\
\hline
\end{tabular}

Source: Primary Data 
The results of the statistical test of the one-sample t-test in Table 10. The significance value is 0,00 and therefore $\mathrm{H} 0$ is rejected, meaning that the percentage of profits from the farmers of Tuberose flowers are higher than the bank loan interest of $17,5 \%$, which means that Tuberose farming is profitable and feasible to be developed.

The results of the statistical test of the one-sample t-test in Table 11. The significance value is 0,00 and therefore $\mathrm{H} 0$ is rejected, meaning that the percentage of profits from the farmers of Tuberose flowers are higher than the bank deposit interest of $4,5 \%$, which means that Tuberose farming is profitable and feasible to be developed. According to the research results of Santoso, A (2006), the tuberose flower agribusiness is prospective and profitable in supporting people's income with an average profit rate of $257 \%$ a year by calculating the harvest time for 6 months.

\section{CONCLUSION}

Based on the research results, it can be concluded that:

1. The use of number of seeds, the number of organic fertilizers, the amount of NPK fertilizer, the amount of labor, and the amount of water have a significant effect on the production of Tuberose flowers. Meanwhile, the use of the number of pesticides has no effect.

2. The amount of flower production, the price of flowers, and labor costs have a significant effect on the income of the farmers of Tuberose flower. Meanwhile, land rental costs, seed costs, organic fertilizer costs, NPK fertilizer costs, and pesticide costs have no effect.

3. Tuberose farming is profitable and feasible to be developed.

Based on the results of the discussion and conclusions, it can be suggested that:

1. The use of Tuberose flower seeds greatly affects production. The seeds used by farmers are local seeds. It is not yet certified. It has mixed quality. Purification of improved seeds is needed to improve the quality and quantity of production as well as registration of varieties from the regency to the Ministry of Agriculture in Jakarta.

2. The flower price affects farmers' income. The high price fluctuations still become a problem at the farmer level. This is because the planting season is the same between West Java, Central Java, and East Java, and the main destination of selling all flowers is the Rawa Belong market in Jakarta. Therefore, it is necessary to increase partnerships and expand market networks through social media in order to obtain stable and profitable prices.

\section{REFERENCES}

Ardiansyah, M., D. Noeriati, and Muhandoyo. 2013. Penawaran dan permintaan bunga sedap malam (Polianthes tuberosa L) di Desa Rembang Kecamatan Rembang Kabupaten Pasuruan. Primordia 9(2): 53-73.

Balai Penelitian Tanaman Hias. 2015. Budidaya Sedap Malam. Brosur. Direktorat Jenderal Hortikultura.

Baruah, N. and M. C. Talukdar. 1998. Response of tuberosa (Polianthes tuberosa) with increasing doses of NPK. Indian Jurnal Agric. Sci 68(9).

Chang, Y. P. 1998. Daylength affects protein pattern and flowering in tuberose (Polianthes tuberose L.). Bot. Bull. Acad. Sin. 39: 199-203.

Dinas Pertanian dan Ketahanan Pangan Kota Bandung. 2008. Standar Operasional Prosedur (SOP) Sedap Malam.

Hartatik, W and Widowati. 2006. Pupuk Organik dan Pupuk Hayati. Jakarta. Balai Besar Litbang Sumberdaya lahan Pertanian. 
Komariah, N. 1990. Pengaruh jarak tanam, dosis pupuk urea dan TSP terhadap pertumbuhan dan hasil bunga sedap malam kultivar Sukabumi. Undergraduate Thesis. Uninus Bandung.

Rukmana, R. 1995. Sedap Malam. Yogyakarta. Kanisius.

Santosa, A. 2006. Prospek agribisnis berbasis tanaman hias usaha bunga sedap malam dan anggrek vanda douglas (Tinjauan khusus usahatani, harga dan permintaan). Caraka Tani 21(1): 1-8.

Sharga, A. N. 1989. Studies on the effects of foliar nutrition on vegetative growth, floral characters and essential oil content of Tuberosa (Polianthes tuborosa). Indian. Jurnal Hort 46(2): 224-249

Shinta, A. 2011. Analisis usaha tani. Malang. Universitas Brawijaya Press.

Sihombing, D., Dewi, I. R. Kasmiati and W. Handayati. 2012. Kajian pengaruh jarak tanam dan ukuran benih terhadap pertumbuhan dan produksi bunga sedap malam varietas roro anteng. Prosiding. Proceeding Seminar Nasional Pekan Inovasi Teknologi Hortikultura Nasional.

Soekartawi. 2016. Analisis Usahatani. Jakarta. Penerbit Universitas Indonesia.

Tejasarwana, R., A. Warsito and R. W. Prasetyo. 2004. Pengaruh ukuran umbi dan umur simpan bibit terhadap produktifitas tanaman sedap malam. Jurnal Hortikultura 14: 326-333.

Wasito, A. and R. Tedjasarwana. 2003. Peningkatan mutu bunga dan produktivitas dua kultivar sedap malam dengan pemupukan $\mathrm{N}, \mathrm{P}$ dan $\mathrm{K}$. Jurnal Hortikultura 13(3): 177-181.
Williams, C. N., Uzo and W.T.H Peregrine. 1993. Vegetable production in the tropics. Translated by I. H.

Ronoprawiro. Yogyakarta. Gadjah Mada University Press. 